\title{
IDENTIFIKASI HURUF BRAILLE BERBASIS IMAGE PROCESSING SECARA REAL TIME
}

\author{
Dewi Permata Sari, Sabilal Rasyad, Evelina, Amperawan \\ Jurusan Teknik Elektro, Program Studi DIII Teknik Elektronika, \\ Politeknik Negeri Sriwijaya, Palembang, Jl. Srijaya Negara 30139 \\ Telp : 0711-353414, Fax. 0711-355918 \\ e-mail:depeesbaker@gmail.com
}

\begin{abstract}
ABSTRAK
Teknologi pengolahan citra digital (Digital Image Processing) saat ini berkembang sangat pesat, maka dapat mempermudah kehidupan manusia dalam banyak aplikasi yang dapat menerapkannya. Pengolahan citra adalah pemprosesan citra menggunakan komputer yang kualitasnya lebih baik dalam mengenal obyek. Dengan memanfaatkan teknologi tersebut, maka diharapkan adanya suatu aplikasi yang dapat mengenal suatu obyek yang ada di depan kamera, bisa mengidentifikasi jenis objek secara realtime. Dengan menggunakan webcam dapat melakukan pengambilan citra sehingga akan didapatkan gambar objek yang akan di identifikasi dengan benar/ tepat. Gambar objek diproses dengan mengidentifikasi dan melakukan tracking gambar objek tersebut. Setelah didapatkan citra gambar objek kemudian proses selanjutnya adalah membandingkan dengan database. Apabila cocok dengan database, maka keluaran yang dihasilkan berupa identifikasi huruf abjad dan data biner dari Arduino UNO. Hasil dari Penelitian ini bertujuan untuk mengidentifikasi huruf Braille dengan benar secara real-time dengan benar. Dari hasil Pengujian huruf Braille dengan kamera Logitech C600 menggunakan waktu dari 3 detik sampai dengan 5 detik maka tingkat akurasi $=92,3 \%$ dan error $=7,7 \%$. Sedangkan Pengujian huruf Braille dengan kamera Logitech C600 menggunakan waktu dari 6 detik sampai dengan 10 detik maka tingkat akurasi $=100 \%$ dan error $=0 \%$.
\end{abstract}

Kata Kunci : Image Processing, Template Matching, OpenCV, Visual Studio

\section{ABSTRACT}

Digital image processing technology is currently growing very rapidly, it can simplify human life in many applications that can apply it. Image processing is image processing using a computer that is better in recognizing the quality of the object. By utilizing these technologies, it is expected that an application that can recognize an object in front of the camera can identify the type of object in realtime. By using the Logitech C600 camera can make the image so that image will be obtained object that will be in the identification with the right/ proper. Image object is processed using identify and track the image of the object. After the image obtained object image and then the next process is to compare with the database. If it matches the database, the resulting output is the identification of alphabet letters and binary data from Arduino UNO. The results of this study aims to correctly identify the Braille letters in real-time. From Braille test results with Logitech C600 camera using time from 3 seconds to 5 seconds then the accuracy rate $=92.3 \%$ and error $=7.7 \%$. While testing Braille letters with Logitech C600 camera using time from 6 seconds to 10 seconds then the accuracy rate $=100 \%$ and error $=0 \%$.

Keywords : : Image Processing, Template Matching, OpenCV, Visual Studio 


\section{PENDAHULUAN}

Teknologi pengolahan citra digital saat ini berkembangan sangat pesat sehingga mempermudah kehidupan manusia dalam banyak aplikasi yang dapat menerapkannya. Pengolahan citra adalah pemprosesan citra menggunakan komputer yang kualitasnya lebih baik dalam mengenal obyek. Dengan memanfaatkan teknologi tersebut, maka diharapkan adanya suatu aplikasi yang dapat mengenal suatu obyek yang ada di depan kamera, bisa mengidentifikasi jenis objek secara realtime.

Dengan menggunakan webcam dapat melakukan pengambilan citra sehingga akan didapatkan gambar objek yang akan di identifikasi dengan benar/ tepat. Setelah didapatkan citra gambar objek kemudian proses selanjutnya adalah melakukan perbandingan dengan database yang telah ada. Apabila cocok dengan database, maka keluaran yang dihasilkan berupa identifikasi huruf abjad dan data biner dari Arduino UNO. Hasil dari Penelitian ini bertujuan untuk membuat prototip yang dapat mengidentifikasi hurup Braille secara real time dengan benar. Metode pengidentifikasian objek yang di aplikasikan pada penelitian ini yaitu menggunakan software visual studio pendukung yaitu OpenCV. Tujuan digunakannya untuk membandingkan image dengan data objek melalui tracking objek secara sederhana dan tidak terlalu rumit. Ada beberapa tahapan dalam proses pengambilan objek ini diantaranya yaitu proses pengambilan gambar dari kamera Logitech C600 untuk database gambar yang dimaksudkan, dan kemudian proses matching antara gambar database dengan gambar yang di identifikasi oleh webcam secara real time, sehingga program dapat membandingkan gambar database yang tersimpan dengan gambar yang diidentifikasi dari webcam. Apabila cocok dengan database, maka keluaran yang dihasilkan berupa huruf abjad sesuai dengan gambar objek. Hasil dari penelitian ini bertujuan untuk mengidentifikasi huruf Braille secara real time, sehingga dapat membantu para guru dan tuna netra dalam belajar mengenal huruf Braille.

Tujuan dari Penelitian ini adalah membuat prototip dapat mengenal huruf Braille melalui kamera Logitech C600 dengan benar secara real time. Untuk pengembangan lebih lanjut dapat dikembangkan untuk mengenal angka dan satu kata Braille.

\section{TINJAUAN PUSTAKA Pengertian Citra}

Manusia adalah mahluk visual dengan cukup mengandalkan penglihatan untuk memahami dunia sekitarnya. Manusia melihat sebuah benda tidak hanya untuk mengidentifikasi dan mengklasifikasi, tetapi juga dapat mengetahui perbedaan dan merasakan secara cepat. Citra didefinisikan sebagai fungsi dari dua variabel misalnya a(x,y) dimana a sendiri sebagai amplitudo (misalnya kecerahan) citra pada koordinat (x,y) (Priyanto, 2017). Oleh karena citra merupakan matrik dua dimensi dari fungsi intensitas cahaya, maka referensi citra menggunakan dua variabel yang menunjuk posisi pada bidang dengan sebuah fungsi intensitas cahaya yang dapat dituliskan sebagai $f(x, y)$ dimana $f$ adalah nilai amplitudo pada koordinat spasial $(\mathrm{x}, \mathrm{y})$. Karena cahaya merupakan salah satu bentuk energi, $\mathrm{f}(\mathrm{x}, \mathrm{y})$ tidak berharga nol atau negatif dan merupakan bilangan berhingga, yang dalam pernyataan matematis adalah sebagai berikut, $0<\mathrm{f}$ (x.y) (Hendy,2013).

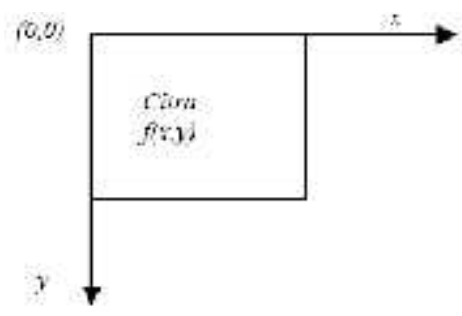

Gambar 1. Sistim koordinat citra diskrit 


\section{Pengolahan Citra}

Pengolahan citra adalah cabang ilmu informatika untuk memperbaiki kualitas citra agar kualitasnya lebih baik atau lebih mudah diinterprestasi oleh manusia maupun komputer. Masukan dari program pengolahan citra adalah citra dan keluarannya pun citra pula (Priyanto, 2017). Citra atau image adalah angka, dari segi estetika, citra atau gambar adalah kumpulan warna yang bisa terlihat indah, memiliki pola, berbentuk abstrak dan lain sebagainya. Citra dapat berupa foto udara, penampang lintang (cross section) dari suatu benda, gambar wajah, hasil tomografi otak dan lain sebagainya. Dari segi ilmiah, citra adalah gambar 3-dimensi (3D) dari suatu fungsi, biasanya intensitas warna sebagai fungsi spatial $\mathrm{x}$ dan $\mathrm{y}$. Di komputer, warna dapat dinyatakan, misalnya sebagai angka dalam bentuk skala RGB. Karena citra adalah angka, maka citra dapat diproses secara digital. Citra merupakan gambar pada bidang dwimatra (dua dimensi) sedangkan dilihat dari sudut pandang matematis, citra merupakan fungsi kontinyu dari intensitas cahaya pada bidang dwimatra. Representasi citra dari fungsi kontinyu menjadi nilai-nilai diskrit disebut sebagai digitalisasi atau citra digital (Suryo, 2012).

\section{Red-Green-Blue}

Untuk citra berwarna maka digunakan model RGB (Red-Green-Blue), satu citra berwarna dinyatakan sebagai 3 buah matrik grayscale yang berupa matrik untuk Red (R-layer), matrik Green (G-layer) dan matrik untuk Blue (B-layer). R-layer adalah matrik yang menyatakan derajat kecerahan untuk warna merah (misalkan untuk skala keabuan 0-255, nilai 0 menyatakan gelap (hitam) dan 255 menyatakan merah. G-layer adalah matrik yang menyatakan derajat kecerahan untuk warna hijau, dan B-layer adalah matrik yang menyatakan derajat kecerahan untuk warna biru. Dari definisi tersebut, untuk menyajikan warna tertentu dapat dengan mudah dilakukan, yaitu dengan mencampurkan ketiga warna dasar RGB (Hendy,2013).

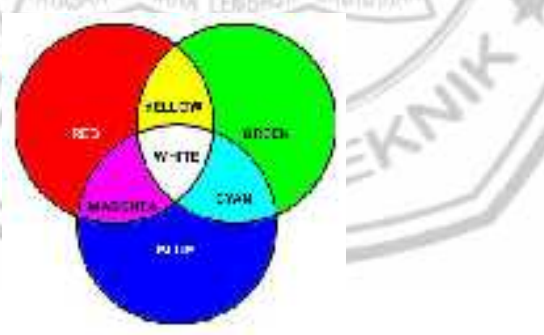

Gambar 2 Komposisi Warna RGB

\section{Grayscale ( Derajat Keabuan )}

Proses awal yang banyak dilakukan dalam image processing adalah mengubah citra berwarna menjadi citra grayscale, hal ini digunakan untuk menyederhanakan model citra. Seperti dijelaskan didepan, citra berwarna terdiri 3 layer matrik yaitu R-layer, G-layer, B-layer. Sehingga untuk melakukan proses selanjutnya tetap diperhatikan 3 layer diatas (Hendy, 2013).

\section{Thresholding}

Thresholding merupakan konversi citra hitam-tadi, maka subjek dapat mengenal bentuk tersebut. Setelah kecocokan antara objek dan template terjadi, proses lebih lanjut dan interpretasi terhadap objek bisa terjadi (Hendy, 2013). Citra digital menjadi objek input yang kemudian diproses sedemikian rupa untuk mendapatkan informasi yang terkandung di dalamnya. Terdapat dua jenis informasi yang dapat diambil dari sebuah citra digital. Pertama adalah informasi sintaksis dan kedua adalah informasi semantik. Informasi sintaksis berkaitan dengan karakteristik fisik dari citra digital antara lain resolusi, kuantisasi, nilai intensitas, tingkat sampling dan sebagainya. Informasi semantik 
berkaitan dengan eksplorasi kandungan makna citra digital yang informasi dikelompokan ke dalam informasi tekstual, figural, fasial, ekspesional, aksional dan situasional/ kondisional. Proses ini disebut juga analisis citra digital yang kelompok ilmunya disebut dengan computer vision (Setiawan, 2016).

\section{OpenCV}

OpenCV adalah singkatan dari Open Computer Vision, yaitu suatu library gratis yang dikembangkan oleh Intel Corporation yang di khususkan untuk melakukan image prosessing. Tujuaannya adalah agar komputer mempunyai kemampuan yang mirip dengan cara pengolahan visual pada manusia. OpenCV mempunyai API (Aplication Programming Interface) untuk high level maupun low level, terdapat fungsi-fungsi yang siap pakai, baik untuk loading, saving, akuisisi gambar maupun video.

\section{Arduino}

Proyek arduino berawal dari institute lvrea, italia pada tahun 2005, sekarang telah lebih dari 120.000 unit terjual sampai dengan 2010. Pendirinya adalah Massimo Banzi dan David Cuartiellez (Abdul, 2013).

Arduino adalah pengendali mikro single-board yang bersifat open-source, diturunkan dari wiring platform, dirancang untuk memudahkan penggunaan elektronik dalam berbagai bidang. Perangkat kerasnya memiliki prosesor Atmel AVR dan perangkat lunaknya memiliki bahasa pemprograman sendiri atau bahasa $\mathrm{C}$ yang disederhanakan dengan bantuan pustaka-pustaka (libraries) yang terdapat pada arduino (Dewi, 2017)

\section{Teknologi Computer Vision}

Teknologi untuk memproses gambar yang telah dikenal antara lain teknologi computer vision dan image processing yang memungkinkan komputer dapat mengenali suatu gambar (citra) digital. Pengenalan pola sintatik adalah suatu pendekatan terhadap suatu pola/citra dilakukan dengan menganalisis struktur pola dari citra.

a. Pola dipilah berdasarkan keserupaan ukuran structural

b. "Pengetahuan" direpresentasikan secara formal grammar atau deskripsi relasional yang menghasilkan deskripsi hirarki dari pola kompleks yang tersusun dari pola bagian yang lebih sederhana (Muhammad, 2013).

\section{Performansi Sistem}

Performansi sistem diukur berdasarkan parameter sebagai berikut:

1. Akurasi Sistem

Akurasi merupakan ukuran ketepatan sistem dalam mengenal Character Error Rate (CER) huruf/ karakter dan mencocokannya dengan data yang berada di database. Akuisisi sistem secara matematis dapat dilakukan seperti pada persamaan 1 dan 2 berikut:

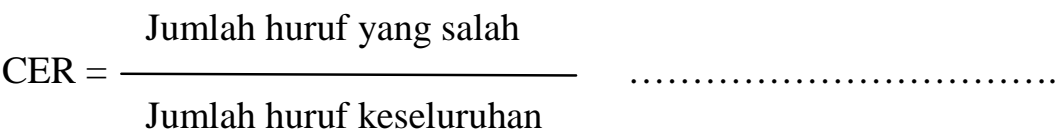

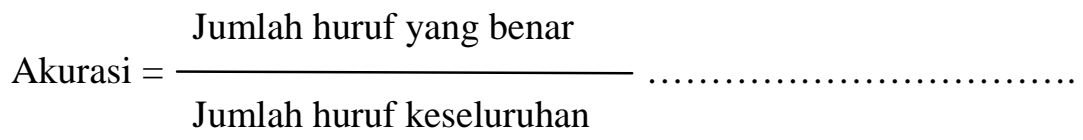




\section{Waktu Komputasi}

Waktu komputasi adalah waktu yang dibutuhkan sistem untuk melakukan suatu proses. Pada sistem ini, waktu komputasi dihitung dengan menggunakan toolbox yang ada di Visual Studio, sehingga didapatkan komputasi sistem.

\section{Huruf Komputer}

Secara umum huruf komputer dapat didefinisikan sebagai sebuah bentuk huruf yang dihasilkan dengan menggunakan suatu standar penulisan yang telah ditetapkan untuk komputer. Terdapat bermacam-macam jenis huruf komputer yang digunakan, beberapa di antaranya adalah Arial, Tahoma, dan Calibri. Variansi visual dari sebuah huruf komputer ditentukan oleh jenis huruf dan ukuran huruf. Hal ini menyebabkan basis pengetahuan yang dibutuhkan untuk melakukan pengenalan huruf dengan sempurna menjadi sangat besar. (Tjokorda, 2009).

\section{Huruf Braille}

Huruf Braille merupakan huruf yang digunakan oleh penyandang tunanetra untuk membaca dan menulis. Huruf Braille dibaca dari kiri ke kanan dan dapat melambangkan abjad, tanda baca, angka, tanda musik simbol matematika dan lainnya. Ukuran huruf Braille yang umum digunakan adalah dengan tinggi sepanjang $0,5 \mathrm{~mm}$, serta spasi horizontal dan vertikal antara titik dalam sel sebesar 2,5 $\mathrm{mm}$. Huruf Braille terdiri dari 6 titik timbul yang mewakili dari huruf dan angka.

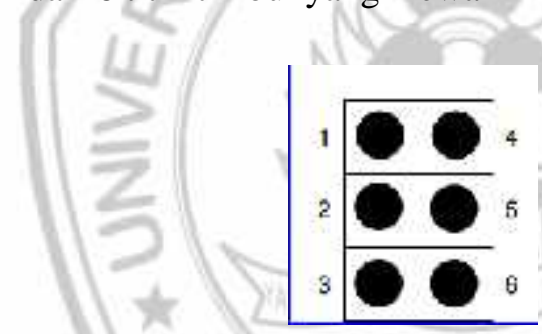

Gambar 3 Huruf Braille

Huruf Braille untuk huruf dan angka terdiri dari 6 buah titik terlihat pada gambar 4 .

\section{BRAILLE Alphabet}

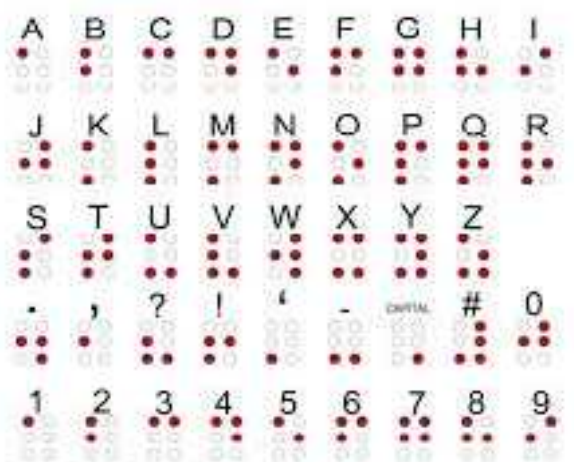

Gambar 4 Huruf dan angka Braille (Dewi, 2017)

\section{METODE PENELITIAN}

\section{Perancangan Sistem}

Pembuatan sistem untuk mengidentifikasi objek, menggunakan webcam komputer/webcam Logitech C600 yang disambungkan ke Personal Computer (PC) untuk menangkap image huruf secara realtime, kemudian gambar diolah menggunakan pengambilan data dari image huruf Braille 
disimpan di database kemudian image akan dibandingkan dengan image database yang telah dibuat diproses secara real time sehingga komputer dapat mengidentifikasi huruf Braille dengan benar/ tepat.

\section{Perancangan Perangkat Keras Dan Perangkat Lunak}

Pada sub bab ini akan dijelaskan bahan dan alat apa saja yang akan digunakan dalam pembuatan sistem pada penelitian ini, diantaranya meliputi :

1. Notebook Compaq Presario CQ42 dengan spesifikasi RAM 2GB, Intel(R) Pentium i5 @ 2,4 $\mathrm{GHz}$

2. Kamera Logitech C600, 8 Mega Pixel

3. Software OpenCV, Visual Studio 2010.

\section{Pembuatan dan Pengujian Perangkat Keras dan Perangkat Lunak.}

Dari hasil perancangan dan implementasi dilakukan pembuatan perangkat keras dan perangkat lunak yang telah dibuat. Dilakukan pengujian masing-masing bagian dari perangkat keras dan perangkat lunak tersebut sebelum dilakukan integrasi.

\section{Integrasi Pengujian Sistem}

Integrasi pengujian sistem guna mengetahui permasalahan-permasalahan yang mungkin muncul diantara lain pengujian :

1. Keberhasilan Capture objek untuk image pembanding pada database objek.

2. Keberhasilan Program dapat melakukan tracking objek benda yang dimaksud.

3. Berapa lama waktu dibutuhkan perangkat lunak untuk membandingkan image dengan database objek.

\section{Experimen Dan Analisa Sistem}

Pada Perancangan sistem pada penelitian ini meliputi:

1. Melakukan instalasi library OpenCV.

2. Melakukan konfigurasi library OpenCV dengan software microsoft visual studio.

3. Melakukan include file-file library yang akan digunakan pada OpenCV pada pemrograman Image Processing.

4. Pemrograman kombinasi antara $O p e n C V$ dan visual studio yang digunakan. 


\section{METODE PENELITIAN}

\section{Sistem Secara Keseluruhan}

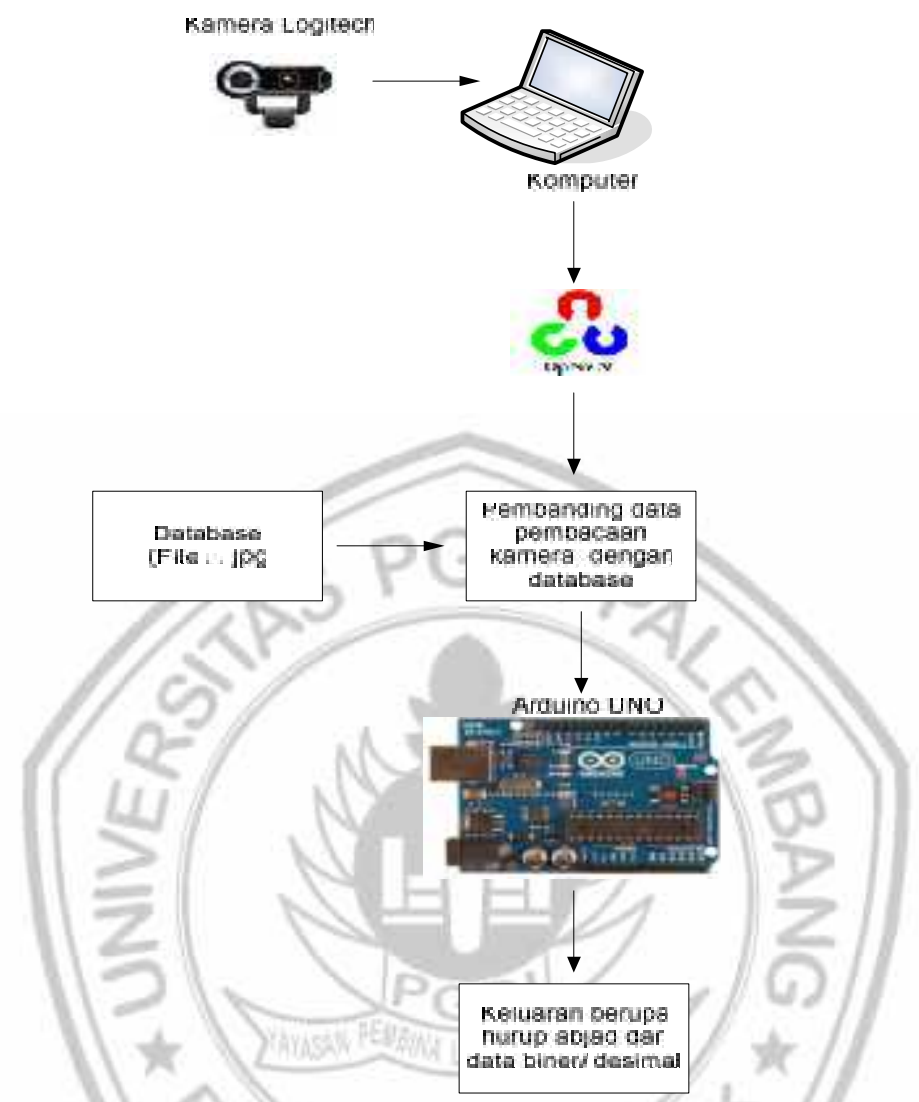

Gambar 5. Perancangan dan Implementasi Sistem

Penjelasan Perancangan dan Implementasi Sistem diatas yaitu melakukan proses pengambilan objek melalui kamera Logitech C600 yang kemudian memproses perangkat lunak visual studio. Untuk proses ini diperlukan adanya gambar pembanding dari database untuk proses tracking object. OpenCV mempunyai Aplication Programming Interface untuk high level maupun low level, digunakan untuk loading, saving, akuisisi image. Dengan proses pengambilan citra akan didapatkan gambar objek untuk di identifikasi dengan benar/ tepat. Citra gambar objek kemudian proses selanjutnya adalah melakukan perbandingan dengan database yang telah ada. Apabila sesuai/ cocok dengan database, maka keluaran yang dihasilkan berupa identtifikasi huruf abjad dan data biner/ desimal dari Arduino UNO berupa indikator LED. 


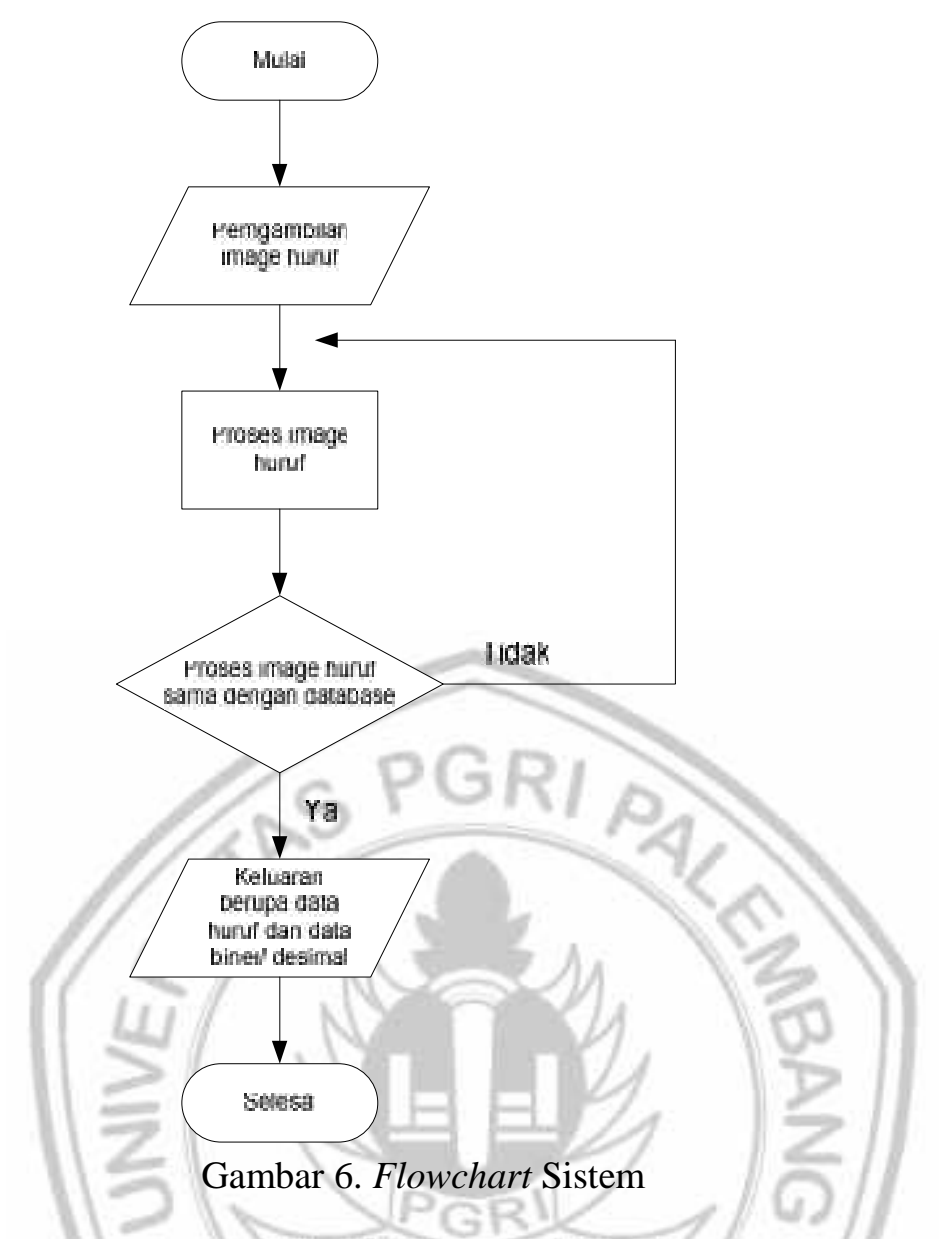

Penjelasan flowchart diatas, melakukan proses masukan objek sebanyak 20 objek dari satu objek, diperlukan adanya gambar pembanding, yang berguna untuk proses tracking object. Jika Objek tidak ditemukan, maka tracking object akan mengambil objek yang paling mendekati objeknya yang disimpan di database, dengan demikian maka objek hurup Braille tersebut dapat diidentifikasi secara real time.

\section{HASIL DAN ANALISA \\ Pengujian}

1. Citra di uji menggunakan kamera Logitech C600.

2. Pengujian dilakukan menggunakan 26 buah citra uji dengan format (.jpg) yang merupakan huruf A sampai dengan $\mathrm{Z}$ yang disimpan didatabase.

3. Melakukan proses identifikasi huruf Braille, kode biner masing-masing huruf Braille dan konnversi desimal.

4. Menghitung besar kesalahan pengenalan karakter per huruf dari A sampai dengan $\mathrm{Z}$ berdasarkan Character Error Rate (CER) dari hasil pengujian.

5. Menghitung waktu identifikasi huruf Braille.

\section{Pengujian Data Hruf Braille}

1. Hasil pengujian huruf Braille dari huruf A sampai dengan huruf $Z$ dengan kamera Logitech C600 pada jarak $30 \mathrm{~cm}$ sampai dengan $60 \mathrm{~cm}$ dengan waktu 3 detik sampai dengan 5 detik didapat hasil pada tabel 1. 
Tabel 1. Pengujian huruf Braille menggunakan kamera Logitech C600 dengan waktu 3-5 detik

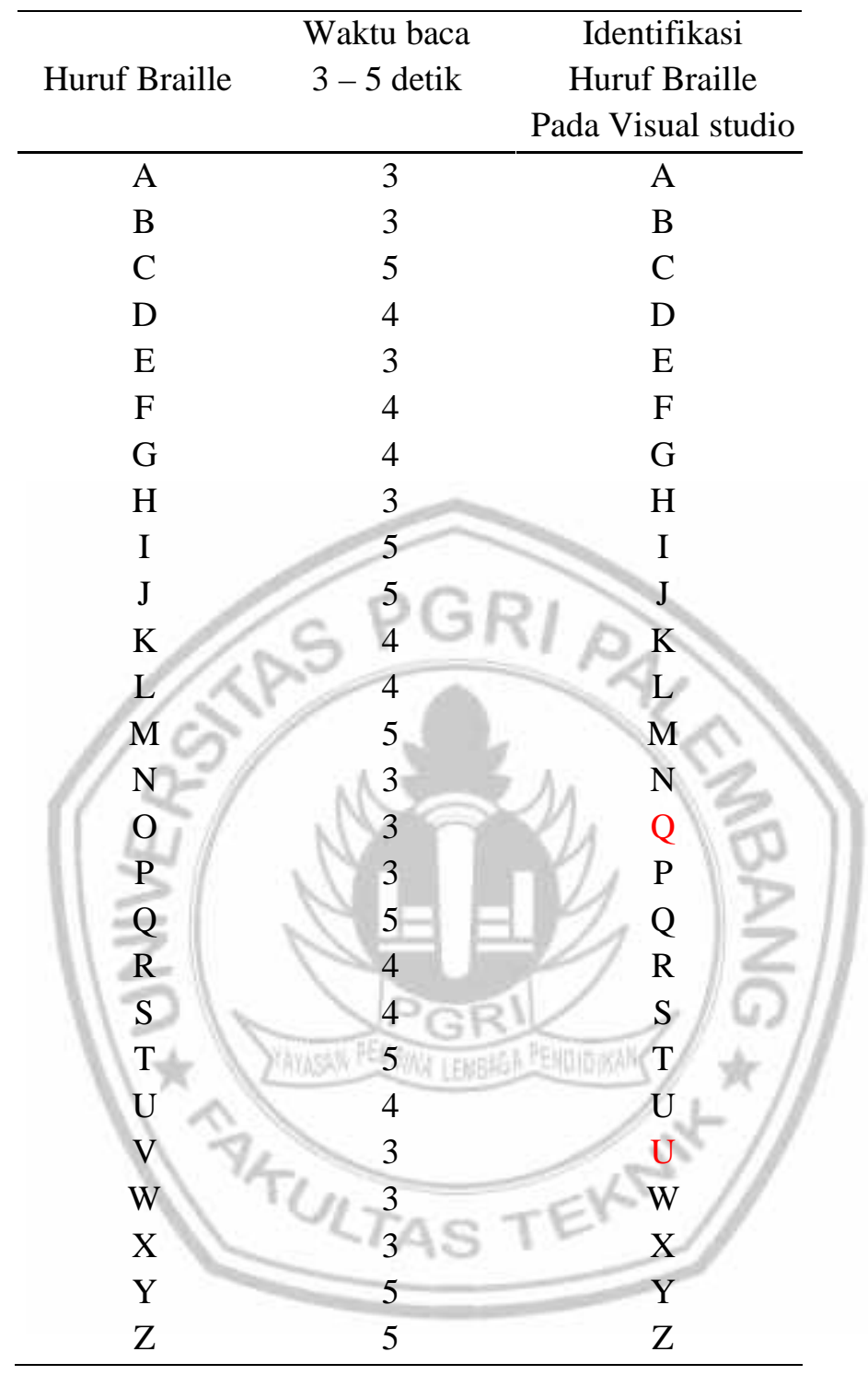

2. Hasil pengujian huruf Braille dari huruf A sampai dengan huruf $Z$ dengan kamera Logitech C600 pada jarak $30 \mathrm{~cm}$ sampai dengan $60 \mathrm{~cm}$ dengan waktu 6 detik sampai dengan 10 detik didapat hasil pada tabel 2.

Tabel 2. Pengujian huruf Braille menggunakan kamera Logitech C600 dengan waktu 6-10 detik

\begin{tabular}{ccc}
\hline Huruf Braille & $\begin{array}{c}\text { Waktu baca } \\
6-10 \text { detik }\end{array}$ & $\begin{array}{c}\text { Identifikasi } \\
\text { Huruf Braille } \\
\text { Pada Visual studio }\end{array}$ \\
\hline A & 6 & A \\
B & 7 & B \\
C & 7 & C \\
D & 6 & D \\
E & 6 & E
\end{tabular}




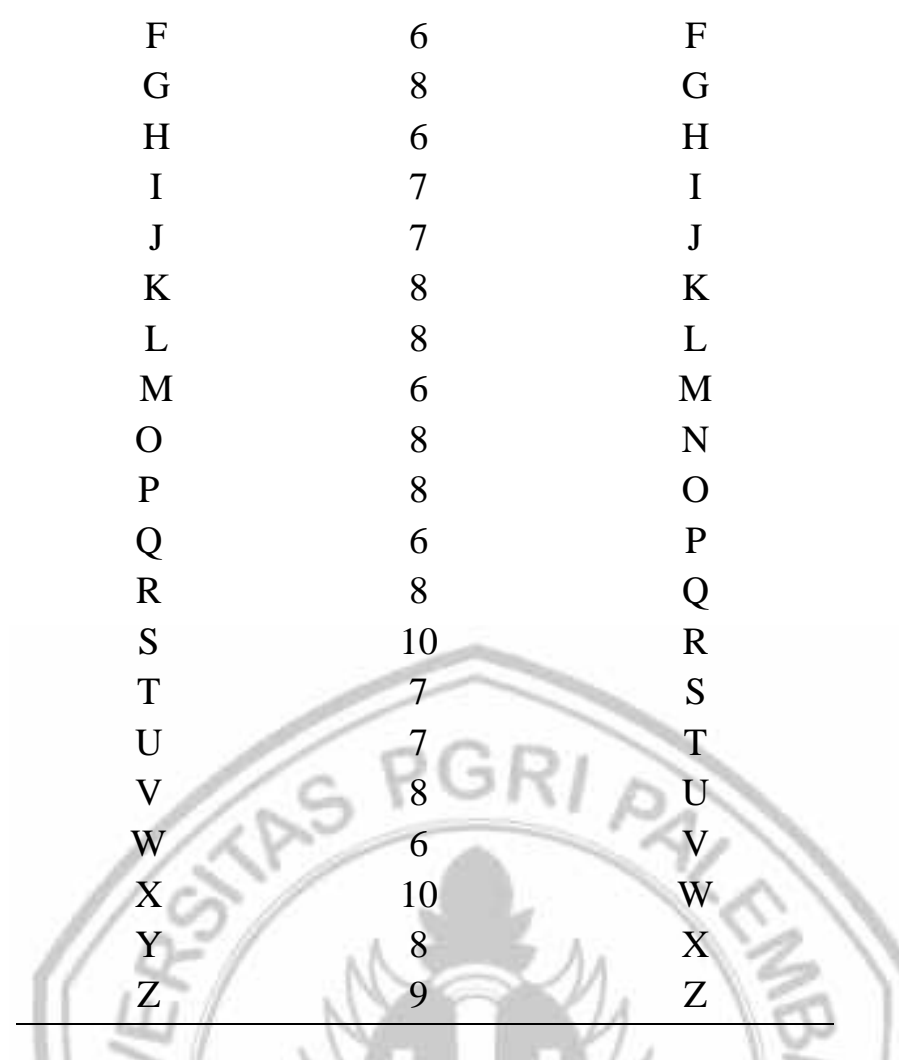

3. Hasil Pengujian Huruf Braille dari A sampai dengan $\mathrm{Z}$ yang berkomunikasi antara kamera Logitech C600 dengan komputer sedangkan board Arduino UNO juga berkomunikasi dengan komputer dimana data huruf dibandingkan dengan database akan menghasilkan huruf abjad sudah benar akan dikonversikan ke dalam data biner dan desimal dengan indikator berupa logika 0 (led akan padam) atau 1 (led akan menyala) yang pada board Arduino UNO keluaran 6 - 5 - 4 3 - 2 pada LED.

Tabel 3. Pengujian Huruf Braille dengan Keluaran 6-5-4-3-2 pada Arduino UNO

\begin{tabular}{cccc}
\hline Huruf Braille & $\begin{array}{c}\text { Identifikasi } \\
\text { Huruf Braille } \\
\text { Pada Visual } \\
\text { studio }\end{array}$ & $\begin{array}{c}\text { Keluaran } \\
\text { Arduino } \\
\text { UNO }\end{array}$ & $\begin{array}{c}\text { Bilangan } \\
\text { Desimal }\end{array}$ \\
\hline A & A & 00001 & 1 \\
B & B & 00010 & 2 \\
C & C & 00011 & 3 \\
D & D & 00100 & 4 \\
E & E & 00101 & 5 \\
F & F & 00110 & 6 \\
G & G & 00111 & 7 \\
H & H & 01000 & 8 \\
I & I & 01001 & 9 \\
J & J & 01010 & 10 \\
K & K & 01011 & 11 \\
L & L & 01100 & 12 \\
M & M & 01101 & 13 \\
N & N & 01110 & 14
\end{tabular}




\begin{tabular}{llll} 
O & O & 01111 & 15 \\
O & O & 10000 & 16 \\
P & P & 10001 & 17 \\
Q & Q & 10010 & 18 \\
R & R & 10011 & 19 \\
S & S & 10100 & 20 \\
T & T & 10101 & 21 \\
U & U & 10110 & 22 \\
V & V & 10111 & 23 \\
W & W & 11000 & 24 \\
X & X & 11001 & 25 \\
Z & Z & 11010 & 26 \\
\hline
\end{tabular}

Hasil pengujian huruf Braille yang dikode biner pada Arduino UNO pada jarak $30 \mathrm{~cm}$ sampai dengan $60 \mathrm{~cm}$ dengan waktu maksimum 10 detik didapat hasil terllihat pada tabel 3 .

\section{PEMBAHASAN}

Pada Tabel 1. Pengujian Huruf Braille dengan kamera Logitech C600 melalui komunikasi komputer yaitu dengan mengambil 26 image huruf Braille.

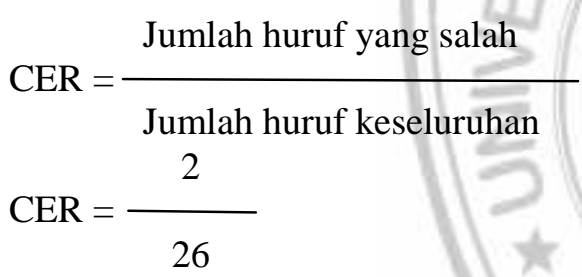

$\mathrm{CER}=0,07 \%$.

$$
\begin{aligned}
& \text { Akurasi }=\frac{\text { Jumlah huruf yang benar }}{\text { Jumlah huruf keseluruhan }} \\
& \text { Akurasi }=\frac{24}{26}
\end{aligned}
$$

Akurasi $=92,3 \%$

Jika menggunakan waktu dari 3 detik sampai dengan 5 detik maka tingkat akurasi 92,3\% dan error $=7,7 \%$. Jika menggunakan waktu dari 6 detik sampai dengan 10 detik maka tingkat akurasi $100 \%$ dan error $=0 \%$.

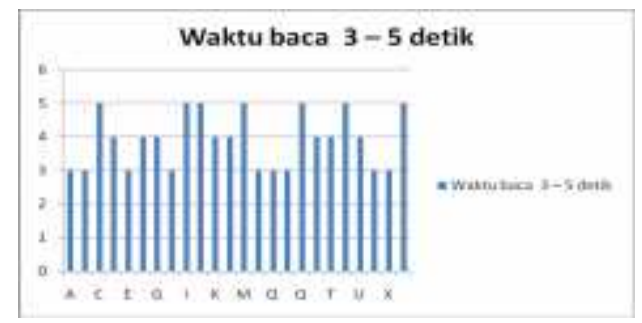

Gambar 7. Pengujian Huruf Braille dengan kamera Logitech C600 melalui komunikasi komputer menggunakan waktu 3-5 detik 


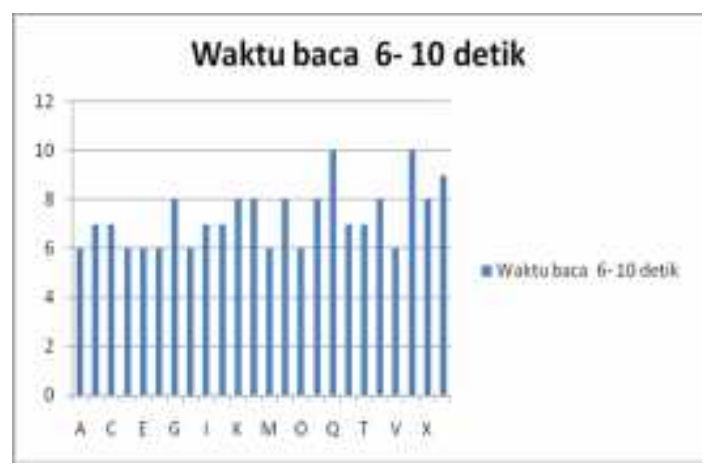

Gambar 8. Pengujian Huruf Braille dengan kamera Logitech C600 melalui komunikasi komputer menggunakan waktu 6-10 detik

Pada Tabel 3 Pengujian Huruf Braille dengan kamera Logitech C600 melalui Arduino UNO dengan Keluaran 6-5-4-3-2 pada tingkat akurasi $100 \%$ dan error $=0 \%$. Hasil Konversi data biner dan desimal dengan indikator LED dari huruf A sampai dengan $Z$ tingkat akurasi $100 \%$ dan error $=0 \%$.

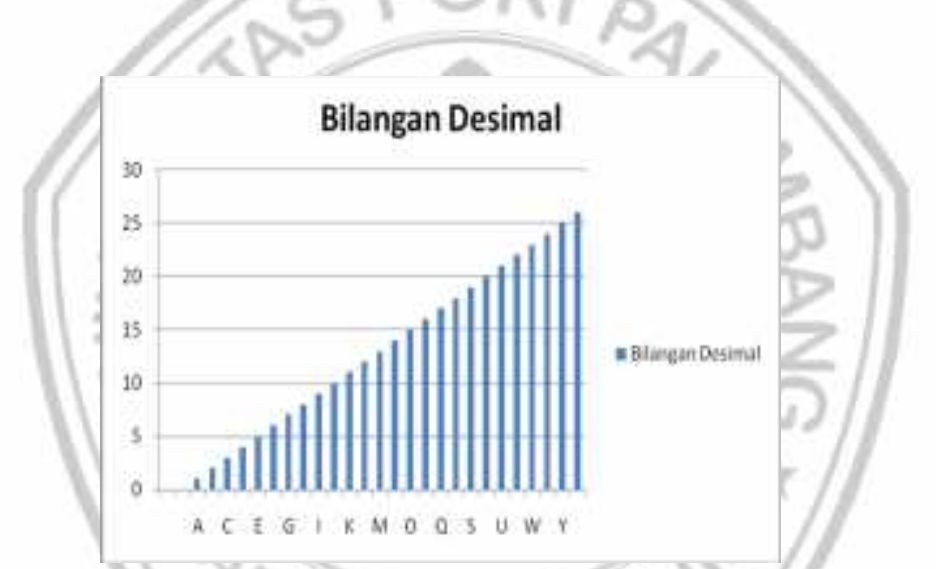

Gambar 9. Pengujian Huruf Braille dengan kamera Logitech C600 melalui Arduino UNO menggunakan waktu maksimun 10 detik

\section{KESIMPULAN}

Dari pengujan yang dilakukan, dapat diambil suatu kesimpulan sebagai berikut :

1. Identifikasi huruf Braille yang sangat baik menggunakan webcam pada jarak $30 \mathrm{~cm}$ sampai dengan $60 \mathrm{~cm}$.

2. Pengujian huruf Braille menggunakan waktu 3 menit sampai dengan 5 menit dengan kamera Logitech maka tingkat akurasi $92,3 \%$ dan error $=7,7 \%$.

3. Pengujian Huruf Braille menggunakan waktu 6 menit sampai dengan 10 menit dengan kamera Logitech maka tingkat akurasi $100 \%$ dan error $=0 \%$.

4. Konversi dari hurup ke desimal dengan waktu lebih kecil sama dengan 10 menit tingkat akurasi $100 \%$ dan error $=0 \%$.

\section{DAFTAR PUSTAKA}

1. Dahria, Muhammad; Pengenalan Pola Wajah Menggunakan Webcam Untuk Absensi Dengan Metode Wavelet, Jurnal SAINTIKOM Vol. 12, No. 2, 2013

2. Hadi, Setiawan; Modul Pratikum Pengolah Citra Digital Teori dan Aplikasi, Universitas Padjajaran, Bandung, 2016 
3. Hartanto, Suryo; Pengukuran Bekal Awal Belajar dan Pengembangan Tesnya, Journal of informatic Ilmu and Technolog, Volume 1, No. 1. 2012

4. Hidayatullah, Priyanto; Pengolah Citra Digital Teori dan Aplikasi, Penerbit Informatika, Bandung, 2017

5. Kadir, Abdul; Pengolah Citra Digital Teori dan Aplikasi, Penerbit Informatika, Bandung. 2017

6. Mulyawan, Hendy, Samsono, H.Z.M., Setiawardhana; Identifikasi dan Tracking Objek Berbasis Image Processing Secara Real Time. Politeknik Elektronika Negeri Surabaya, Institut Teknologi Sepuluh Nopember (ITS) Surabaya, 2013

7. Sari, P., Dewi; Pena Elektronik Untuk Bantu Baca Tuna Rungu Dan Tuna Netra, Laporan Kemajuan Penelitian Produk Terapan RISTEKDIKTI, 2017

8. Wirayuda, B.,A., Tjokorda. 2009. Pengenalan Huruf Komputer Menggunakan Algoritma Berbasis Chain Code dan Algoritma Sequence Alignment. Konferensi Nasional Sistem dan Informatika Konferensi Nasional Sistem dan Informatika, Bali, 2009

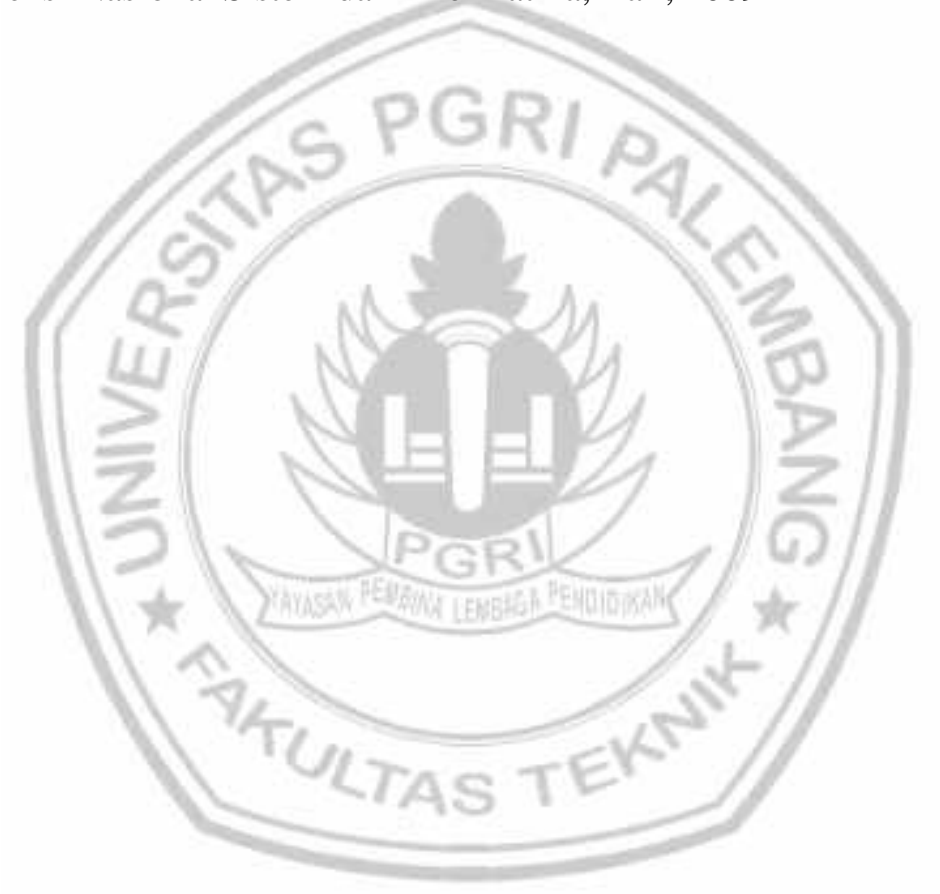

